\title{
Improvement of storage resistance of sausage products to micellar mushrooms by synthetic protective shrinks
}

\author{
K.O. Rodionova1 , A.P. Paliy 2,3 , A.P. Palii3 , I.V. Yatsenko4, N.M. Bogatko5, Y.V. Vashchyk6, \\ S.A. Zolotaryova7, L.I. Nalyvayko ${ }^{6}$, A.P. Zolotarev ${ }^{8}$, H.V. Ovcharenko ${ }^{6}$ \\ ${ }^{1}$ Odessa State Agrarian University, 13 Panteleimonovskaya St, Odessa, 65012, Ukraine \\ ${ }^{2}$ National Scientific Center "Institute of Experimental and Clinical Veterinary Medicine", \\ 83 Pushkinska St, Kharkiv, 61023, Ukraine \\ ${ }^{3}$ Kharkiv National Technical University of Agriculture named after Petro Vasylenko, \\ 44 Alchevskih St, Kharkiv, 61002, Ukraine \\ ${ }^{4}$ Kharkiv State Zooveterinary Academy, village Malaya Danilovka, \\ 1 Akademicheskaya St, Dergachevsky district, Kharkiv region, 62341, Ukraine \\ ${ }^{5}$ Bila Tserkva National Agrarian University, \\ 8/1 Cathedral Square, Bila Tserkva, Kyiv region, 09111, Ukraine \\ ${ }^{6}$ Luhansk National Agrarian University, \\ 68 Slobozhanska St, Starobelsk, Lugansk region, 92703, Ukraine \\ ${ }^{7}$ Kharkov National Agrarian University. V.V. Dokuchaev, \\ poststation "Dokuchaevskoye - 2", Kharkiv region, 62483, Ukraine \\ ${ }^{8}$ Institute of Animal Science of the National Academy of Agrarian Sciences of Ukraine, \\ 1-A Tvarynnykiv St, Kharkiv, 61026, Ukraine \\ *Corresponding author E-mail: katerina.rodionova@ukr.net
}

Received: 09.08.2020. Accepted 29.09.2020

\begin{abstract}
The aim of the work was to establish the frequency of detection of mold of raw smoked sausages and to evaluate the use of synthetic protective shrinks, which provide long-term storage of sausages. Nine batches (310 samples) of raw smoked sausages were examined, 487 crops were made on special media, 154 samples of sausages were examined according to physical and chemical parameters. We determined that an intensive contamination of their surface with micellar fungi during the sale of raw smoked sausages in retail trade is taking place: Penicillium(62.9\%), Aspergillus (18.2\%), Mucor(10.7\%), Cladosprium(4.5\%). We found that on the $5^{\text {th }}$ day of their sale $4.57 \pm 1.64 \%$ of experimental sausage bulks are contaminated with micellar fungi but more massive and intensive development of micromycelia was found on the $20^{\text {th }}$ day of sale $(29.32 \pm 8.16 \%$ of cases). We proved that the use of protective coating/srink "Optiglianets" (Lofink Group, Ukraine), "CoatStar 110" (OJSC "Upakprint", Russia), "Polisved1" (OJSC "Omega”, Russia), "Antibak Tauchmassa” (Company “Swed Holding”, Russia) and “Tauchmasse KP-15", Italy), delayed up to 20 days the development of micellar fungi on the surface of prototypes of smoked sausages. We applied them in a thin layer (0.06-0.10 $\mathrm{mm}$ depending on the applied means) on the surface of sausage bulks and dried in drying chambers at temperature of $15.0 \pm 2.0^{\circ} \mathrm{C}$ and 45 minutes exposure at a relative humidity of $70 \%$. The weight loss of raw smoked sausages was the lowest with the use of protective coating "Optiglyanets" (Lofink Group, Ukraine) and "Polisved-1" (OJSC "Omega", Russia). It was $14.5 \pm 0.8 \%$ and equal to $60 \%$ reduction compared to other protective coatings/shrinks implementation.

Key words: sausage, variety, protective shells, micromycetes, contamination.
\end{abstract}

\section{Introduction}

To obtain quality and safe meat products is possible only with strict adherence to all technological and technical techniques that are implemented in meat processing enterprises of various forms of ownership (Paliy et al., 2018). Along with the quality control of raw materials, it should be paid great attention to the possible contamination of products by foreign microflora (Paliy et al., 2017; Rodionova et al., 2020).

Toxic secondary metabolites (mycotoxins), which are produced by micellar fungi, nowadays can be found on the surface of food, including bulks of sausage. The most important from the point of view of food and feed safety are aflatoxins, ofratoxin A, patulin, fumonisins, zearalenone, trichothecenes and others. These compounds are produced by several species of micellar fungi belonging to the genera of Aspergillus, Penicillium, Fusarium and Claviceps and may have carcinogenic, mutagenic, 
teratogenic, cytotoxic, neurotoxic, nephrotoxic, estrogenic and immunosuppressive properties (Abrunhosa et al., 2016; Delgado et al., 2016).

Prevention of losses and preservation of quality of sausages is connected, first of all, with their protection against negative influence of microorganisms during production and storage. In this regard, the issues of biological safety of products, i.e. the maximum prevention of biological risk, associated with pathogenic microorganisms on human, are the questions of the first importance in the meat industry in recent years (lacumin et al., 2016; Rodionova \& Paliy, 2018).

Factor that decreases the quality of sausages is contamination of products by contaminants of various origins; however, it is primarily microorganisms that are able to enter the product at any stage of the trophological chain in the case of absence of proper veterinary control in the production (Jessen \& Lammert, 2003).

Mycological studies at meat processing enterprises revealed the absolute dominance (more than $80 \%$ ) of molds of the genus Penicillium, and in a fewer numbers (up to 52.5\%) representatives of the Aspergillus genus, Mucor, Cladosporium, Thamnidium and Rhizopus, both on the surface of meat products and in the air of industrial premises. Yeasts of the genera Candida, Saccharomyces, Rhodotorula, Torulopsis are dominated on the surface of meat products. Bacteria are most often represented by species of the genera Bacillus, Lactobacillus, Pseudomonas, Micrococcus and others (Sachindra et al., 2005).

These microorganisms multiply rapidly when they come on the surface of meat products, and cause various types of spoilage, which not only degrades their appearance, but also causes a potential threat to consumer health due to the production of toxins deep into the sausage. In particular, $P$. commune is a known producer of mycotoxin - cyclopiazoic acid, $P$. verrucosum produces ochratoxin A, P. expansum - patulin, Eurotium amstelodami - sterigmatocystin (Topal, 2004). Cultures of $P$. brevicompactum and $P$. aurantiogriseum have the ability to produce from 5 to 10 different mycotoxins (Ismaiel \& Papenbrock, 2015; Frisvad, 2018).

Huge part of mycotoxins has toxic, carcinogenic and nephrotoxic effects. In small doses, they can change the mechanism of gastric and intestinal digestion in humans. They suppress the human immune system when they come in the blood, and can cause the development of cancer. In addition, micellar fungi destroy the surface of the moldy product, reduce its taste, cause changes in proteins and fats, create favourable conditions for further spoilage of the product (Abrunhosa et al., 2016). It should be noted that the mechanical removal of colonies of mycelial fungi from the surface of food does not exclude their redevelopment and subsequent accumulation of mold metabolites (lacumin et al., 2009).

Thus, preventing the production, sale and consumption of meat products which are affected by molds that can harm the health of the population is one of the most important problems of the meat processing industry (Wu et al., 2013; Boonviset \& Pirak, 2020).

Currently, various sausage coatings/srinks, vacuum packs, polymer coatings, ozone, light radiation with different wavelengths, preservatives, antibiotics and food additives, which are not always useful for human health, are widely used to suppress the activity of microorganisms (Kim et al., 2014; Kocic-Tanackov et al., 2017).

The most common method of combating mold on the surface of sausage bulks is the treatment of sausage shrinks with preparations containing chemical preservatives (salts of sorbic, benzoic, dehydroacetic acids) or antibiotics. There are strict legal restrictions on the use of these compounds in food (Martins et al., 2019). It should be noted that the regulated documents of many countries do not have large differences between the allowable limits of their detection both for a direct addition to the food product, and for application on the surface of the sausage shrinks. The goal of these measures is to ensure guaranteed long-term microbiological safety and maintain high quality sausage products (de Barros et al., 2010; Holck et al., 2017).

Some scientists recommend to use garlic, mustard, horseradish, oak bark, birch, propolis tincture, as natural antimicrobial preservatives, as well as solutions of acetic, benzoic and propionic acid, and others. However, when using these tools, only weak bacteriostatic effects on molds can be achieved (Viera et al., 2016; Tosati et al., 2018).

The use of these measures does not have a negative impact on the organoleptic and physicochemical parameters of products, but improves microbiological ones, which allows us to consider their use in meat production technology to create a safe product by inhibiting the growth of microflora, causing microbiological spoilage of sausages (Acevedo-Fani et al., 2015).

The studies in which the bactericidal activity of silver nanoparticles in artificial sausage shrinks, which retains for 6 months its antimicrobial properties against various strains of pathogenic and opportunistic microorganisms ( $E$. coli and $S$. aureus) and yeast, are increasingly found in the literature. Due to their small size, silver nanoparticles are extremely active and can cause the death of bacteria, viruses, fungi on large square of surfaces because they have a large surface area of culture medium. It increases the contact of silver area with bacteria or viruses significantly increasing its bactericidal properties. Thus, the use of silver in the form of nanoparticles can reduce the concentration of the metal in hundreds of times while maintaining all its bactericidal properties (Marchiore et al., 2017; Wang et al., 2018).

Tauchmasse is a liquid antibacterial shrink for long-storage sausages. It is applied on top of the sausage shrink thereby providing protection against abnormal drying (by ensuring airtightness) and weight loss of the product during transportation and storage (Cagri et al., 2004).

In addition, tauchmasse which is applied on the product provides protection from the harmful effects of light and oxygen, preventing the damage of products. This preventing reduces the amount of used preservatives. After drying on the surface, a transparent glossy shrink is formed, which protects effectively the product from the development of yeast and mold fungi, prevents the crystallization of salt on the surface (Sánchez-Ortega et al., 2014).

In this regard, the urgent question is to find new effective and safe for human means and methods which prevent mold growth in sausages and reduce the intensity of reproduction of micellar fungi on their surface.

The aim of our work was to establish the frequency of detection of mold in smoked sausages and to evaluate the use of synthetic protective shrinks that provide long-term storage of sausages in a comparative aspect. 


\section{Materials and methods}

The experimental part of the work was carried out on the basis of meat processing enterprises of Luhansk and Volyn oblast of Ukraine, the laboratory of veterinary sanitation and parasitology of the National Scientific Center "Institute of Experimental and Clinical Veterinary Medicine" (Kharkiv) and the Department of Infectology, Quality and Safety of Agro-Industrial Complex Products of Luhansk National Agrarian University (Kharkiv).

In carrying out the work it was used generally accepted and special approved research methods. Sampling of sausages for the study was carried out in accordance with GOST 9792-73 "Sausages and products made of pork, lamb, beef and meat of other species of slaughter animals and birds. Acceptance rules and sampling methods".

With the aim to control the external appearance of the product, a sample of $10 \%$ of the batch of raw smoked sausages was taken. There were taken selectively from each batch 2 sausage bulks to carry out organoleptic and chemical studies, and 4 sausage bulks to make bacteriological researcher. Spot samples were taken from the selected units to make combined samples: one for organoleptic tests, the other - for physicochemical studies. Spot samples for determination of organoleptic characteristics were taken in $400 \mathrm{~g}$ weight and for physical and chemical tests $-250 \mathrm{~g}$. There were cut from the product in the transverse direction at a distance of at least $5 \mathrm{~cm}$ from the edge. Two spot samples, from different sausage bulks of one batch, made up united samples in $800 \mathrm{~g}$ weight for organoleptic and $500 \mathrm{~g}$ for physicochemical tests, respectively.

To carry out bacteriological tests, there were taken 4 sausage sample bulks in each batch (necessarily with a closed edge and clips availability). Two spot samples in $15 \mathrm{~cm}$ long each from the edge of the bulk were cut with a sterile knife. One united sample consisted of two spot samples.

Physico-chemical parameters of experimental samples of sausages were determined according to GOST 9793-74 "Meat products. Methods of determination of moisture", GOST 9957-73 "Sausages and products made of pork, lamb and beef. Methods of determination of sodium chloride", GOST 8558.1-78 "Meat products. Methods of determination of nitrite", GOST 23042-86 "Meat and meat products. Methods of determination of fat", GOST 25011-81 "Meat and meat products. Methods of protein determination".

Microbiological studies were carried out in accordance with GOST 9958-81 "Sausage products and meat products. Methods of microbiological analysis". The samples were stored in a refrigerator at $4.0 \pm 1.0^{\circ} \mathrm{C}$ temperature and a relative humidity of $85 \pm 2 \%$. Determination of microbial contamination on the sausages surface was performed by the "sample washes" method. There were made washes with pre-soaked, sterile swabs from the surface of the sausages experimental sample. The obtained samples were sown on a dense nutrient medium Saburo, cultivation was performed in a thermostat TC-80M-2 at $22.0 \pm 1.0^{\circ} \mathrm{C}$ temperature, with further registration of grown colonies in 5 days. Identification of isolated microscopic fungi was performed with the help of microscopy at a magnification of 80 times.

10 samples of synthetic protective shrinks from different manufacturers were used in the experiments (Table 1).

Table 1. Characteristics of experimental synthetic protective shrinks

\begin{tabular}{lcc}
\hline \multicolumn{1}{c}{ Antiseptic coating } & $\begin{array}{c}\text { External } \\
\text { appearance }\end{array}$ & $\begin{array}{c}\text { Producer } \\
\text { (exporter) }\end{array}$ \\
\hline Optiglanets & milky white liquid & Lofink Group, Ukraine \\
Blendex Tauchmass & transparent crystal & Moguntia, Austria \\
Reinforced protective & transparent crystal & Trademark Spasskiy® \\
tauchmasse & transparent tauchmasse & Company JSC GK "Spassky Group" Russia \\
Coutstar 110 & milky white liquid & OJSC "Upackprint", Russia \\
Polisved-1 & OJSC "Omega", Russia \\
Special food mixture & fine-grained granules & Company "Swede Holding", Russia \\
Antiback tauchhmasse & Company "Swede holding" Russia \\
Aspick & transparent liquid & Trobas, the Netherlands \\
Latex coating for sausages and & milky white liquid & LTD "MGK Ukraine" \\
cheeses Tauchmasse & milky white liquid & Italy \\
Tauchmasse KP-15 & & \\
\hline
\end{tabular}

Before application of the protective shinks on the surface of raw smoked sausages, special attention was paid to the fact that the surface of sausage bulks have to be dry, without grease stains. Raw smoked sausages in the shrinks were covered with tauchmasse by immersion (Fig. 1).

The tauchmasse was heated in a water bath to $30-35 \pm 1.0^{\circ} \mathrm{C}$ temperature and mixed thoroughly, before processing the bulks. Ready-to-use synthetic varnishes were also thoroughly mixed. The prepared protective liquid shell was applied to the surface of the experimental raw smoked sausages after the drying process by immersing them one time in the test solution to create a coating along all the length of the product. After flowing down the excess of solution from the product during 2-3 min, the sausages were sent to the drying chamber. The formation of an additional protective shrink on the surface of sausage bulks was performed in drying chambers at $15.0 \pm 2.0^{\circ} \mathrm{C}$ temperature, relative humidity of $70 \%$ and air speed $0.05-0.1 \mathrm{~m} / \mathrm{s}$ during $45 \pm 2$ $\mathrm{min}$. The minimum temperature at which the shrink began to form was $10.0 \pm 2.0^{\circ} \mathrm{C}$. The protective solution was distributed on the surface of the sausage surface forming a shrink with a thickness of $0.08-0.10 \mathrm{~mm}$. 

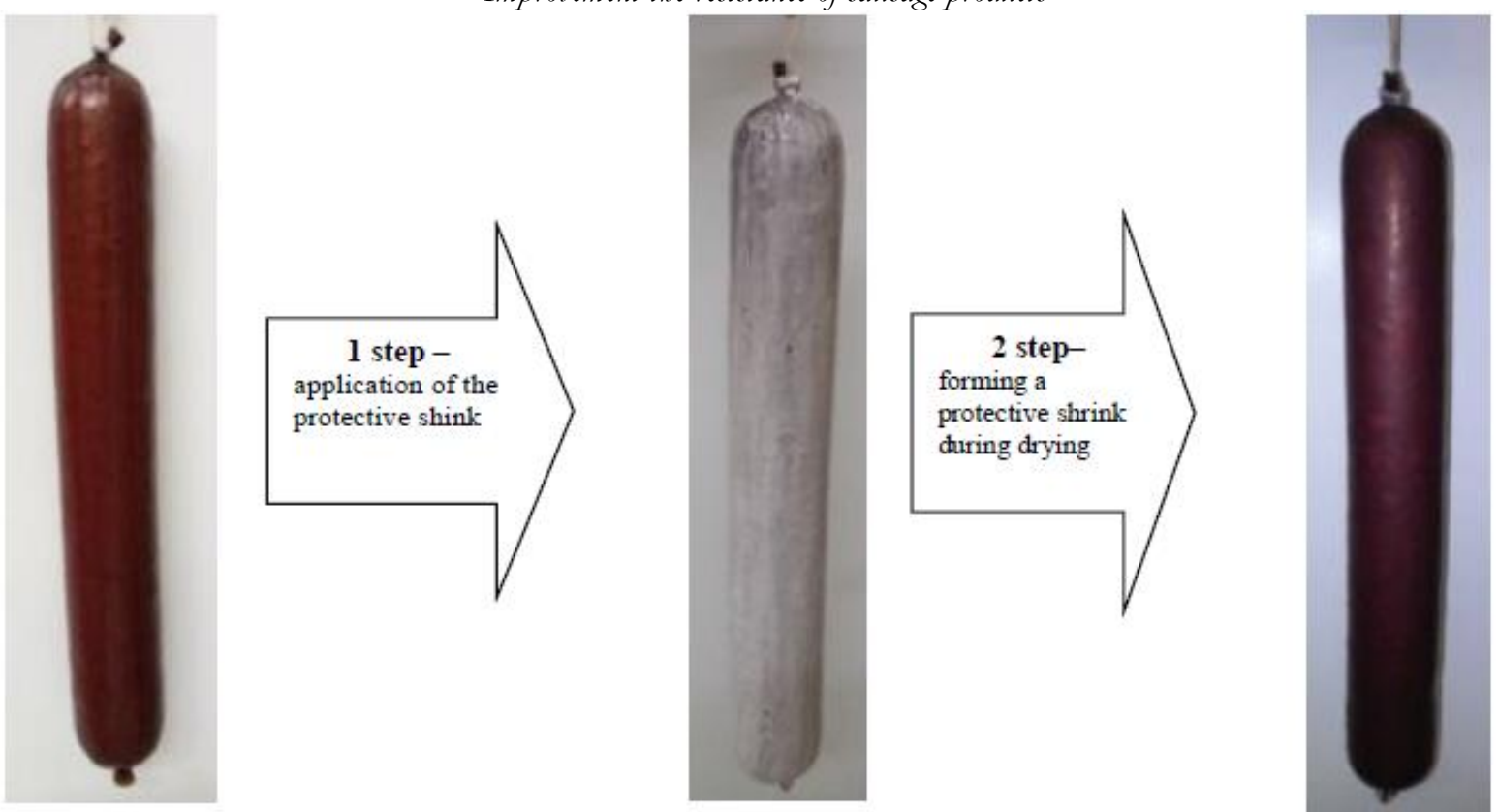

Fig. 1. Technological process of forming a protective shrink on the surface of smoked sausages

Latex protective coating for raw-smoked sausages was also applied by immersing in the finished antibacterial solution the chilled bulks after smoking during 1-2 seconds. At a temperature $15.0 \pm 2.0^{\circ} \mathrm{C}$ in the drying chambers for smoked sausages, the minimum drying time was 45 minutes (at a relative humidity of $70 \%$ ). The minimum temperature at which the shrink began to form was $6.0 \pm 2.0^{\circ} \mathrm{C}$. The protective solution was distributed on the surface of the sausage coating a forming shrink with a thickness of 0.06-0.08 mm. Experimental solutions, in which the bulks were immersed, were used only for one day period to avoid the development of microflora in them.

The end of the coating process was determined visually by paying attention to the formation on the surface of the sausage surface a transparent, non-sticky shrink.

Determination of weight loss of the ready product during storage was performed by the weight method, with weighing accuracy up to $0,01 \mathrm{~g}$.

The calculation of weight loss was performed according to the formula:

$$
P=(m-m i) / m \times 100 \%
$$

where, $m$ - is the mass of the product before storage, $\mathrm{g}$; $m i$ - is the weight of the product during the day of storage, $g$.

Statistical processing of the obtained data was performed on a computer complex using spreadsheets Microsoft Excel XP Professional and STATISTICA 7.0 (Stat Soft, USA). Pearson 's correlation coefficient, which characterizes the level of linear dependence between variables, was calculated using the standard package of licensed statistical application SPSS - 12.0. The obtained results of the correlation index ( $r$ ) were interpreted in this way: up to 0.2 - very weak, from 0.2 to 0.5 - weak, from 0.5 to 0.7 - medium, from 0.7 to 0.9 - high and more than 0.9 - very high.

\section{Results and discussion}

According to the results of our own poll in the largest supermarkets in Kharkiv, it was found that consumers give the main preference among smoked sausages to "Moscovska" premium sort - 48.38\%, in second place -"Braunschweigska" premium sort $-34.63 \%$, in the third place "Sudzhuk" premium sort $-14.21 \%$, other types of sausages $-2.78 \%$.

Analyzing the reasons of the decline in the quality of these types of row smoked sausages in supermarkets in Kharkiv, it was detected that the most common reason of decreasing the commercial appearance of these sausages is the presence of white thin layer on the surface of sausage bulks, indicating the development of micellar fungi. That is why, at the first stage of research, we analyzed the dynamics of the development of microscopic fungi on the surface of raw-smoked sausages. For this purpose, three types of smoked sausages were selected out of 9 batches:

- "Braunschweigska" sausage of the premium sort;

-"Moscovska" sausage premium sort;

- Sausage "Sudzhuk" premium sort.

The results took into account up to 20 days of sale, because according to commodity experts, this period is the maximum for selling of a batch of raw-smoked sausages.

It was found that the germination of mold fungi on single sausage bulks of row-smoked sausages of the experimental group begins on the $5^{\text {th }}$ day of their implementation, but more massive and intensive development of micromycelia was observed on 15-20 days. In 20 days of sale, smoked "Braunschweigska" raw-smoked sausage is covered with mold in $38.47 \pm 4.83 \%$ of cases, "Sudzhuk" in 36.47 $\pm 2.13 \%$, and "Moscovska" raw-smoked sausage in 13.03 $\pm 2.15 \%$ (Table 2). 
Table 2. Dynamics of micromycetes development on the surface of sausage bulks $(n=3, M \pm m)$

\begin{tabular}{|c|c|c|c|c|c|}
\hline \multirow{3}{*}{ Sausage samples } & \multirow{3}{*}{ batch } & \multicolumn{4}{|c|}{ Period of research, day } \\
\hline & & 5 & 10 & 15 & 20 \\
\hline & & \multicolumn{4}{|c|}{ Quantity of bulks covered with mold, $\%$} \\
\hline \multirow{3}{*}{$\begin{array}{l}\text { "Braunschweigska" } \\
r / s, p / s\end{array}$} & 1 & 9.0 & 15.1 & 20.6 & 34.4 \\
\hline & 2 & 4.9 & 21.0 & 32.3 & 48.1 \\
\hline & 3 & 6.1 & 13.1 & 22.9 & 32.9 \\
\hline \multirow[t]{2}{*}{ Average amount } & & $6.67 \pm 1.22$ & $16.4 \pm 2.37$ & $25.27 \pm 3.58$ & $38.47 \pm 4.83$ \\
\hline & 1 & 5.1 & 11.9 & 29.9 & 39.8 \\
\hline \multirow[t]{2}{*}{ "Sudzhuk" r/s, p/s } & 2 & 6.1 & 16.3 & 23.7 & 37.1 \\
\hline & 3 & 5.9 & 12.9 & 22.4 & 32.5 \\
\hline \multirow[t]{2}{*}{ Average amount } & & $5.7 \pm 0.3$ & $13.7 \pm 1.3$ & $25.3 \pm 2.3$ & $36.47 \pm 2.13$ \\
\hline & 1 & 2.9 & 5.0 & 12.4 & 17.0 \\
\hline \multirow[t]{2}{*}{ “Moscovska” r/s, p/s } & 2 & 1.1 & 6.1 & 8.5 & 12.5 \\
\hline & 3 & - & 2.0 & 6.6 & 9.6 \\
\hline Average amount & & $1.33 \pm 0.84$ & $4.37 \pm 1.22$ & $9.16 \pm 1.71$ & $13.03 \pm 2.15$ \\
\hline Grouped average & & $4.57 \pm 1.64$ & $11.49 \pm 3.64$ & $19.91 \pm 5.37$ & $29.32 \pm 8.16$ \\
\hline
\end{tabular}

Analyzing the obtained data, it can be concluded that during the sale in retail stores from 0.04 to $29.32 \%$ of sold bulks of rawsmoked sausages were contaminated with micromycetes. On the 20th day of sale, raw-smoked sausage was contaminated with micellar fungi in $29.32 \pm 8.16 \%$ of cases; it is almost in 6.4 times more than on the fifth day of sale. The analysis of the results of the research revealed a high positive correlation ( $r$ ) between the shelf life of sausage bulks in retail and the total number of mold bulks. It is established that the correlation dependence is equal to $(r=1)$.

We found that the most common reason of mold on the surface of the experimental sausage bulks were micromycetes of the genus Penicillium (62.9\%), Aspergillus (18.2\%) and Mucor (10.7\%). Microscopic fungi of the genera Cladosporium (4.5\%), Thamnidium (2.7\%), and Rhizopus (0.8\%) caused mold much less often. Debaromyces and other micromycetes were detected in isolated cases (0.2\%), and they were not significant in the mold of sausages (Fig. 2).

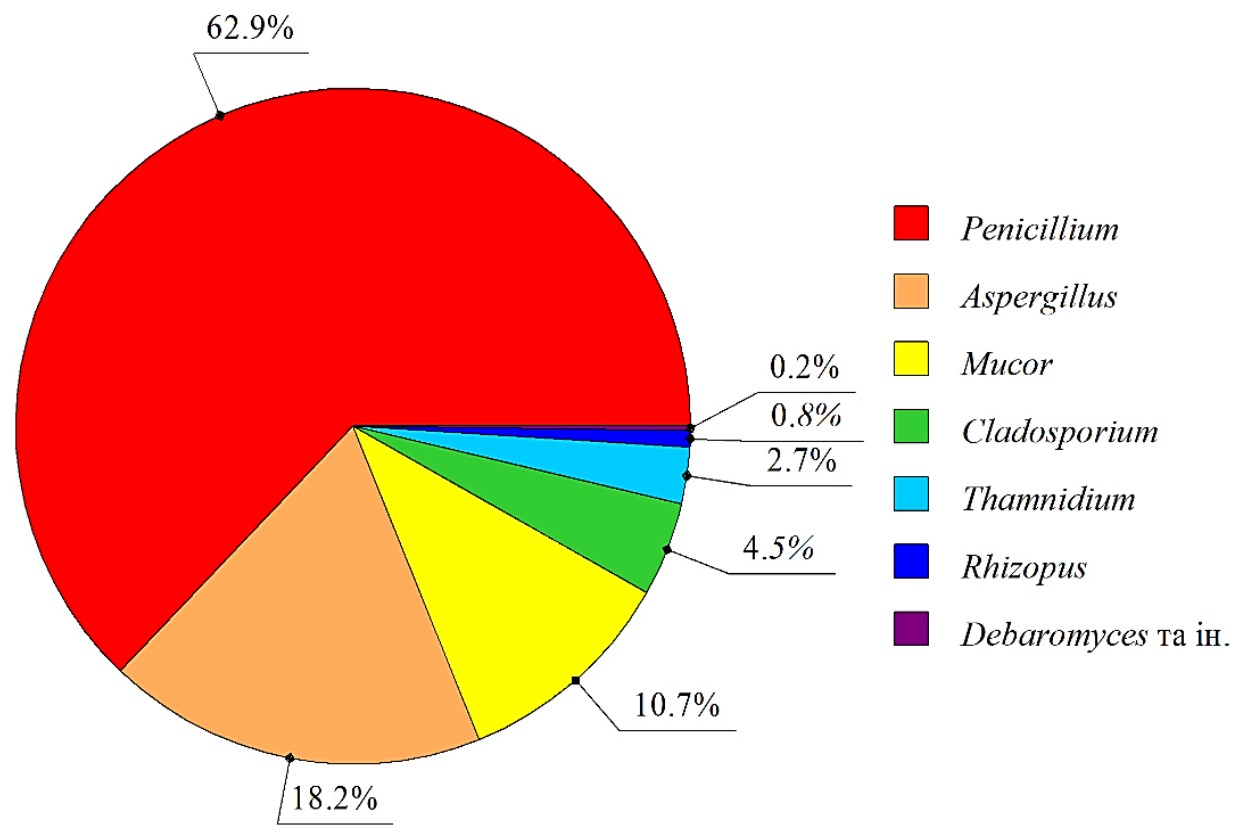

Fig. 2. The results of the identification of molds detected on the surface of raw-smoked sausages, \%

The obtained research results indicate that during the sale of sausages in the trade network they are contaminated with 7 species of micellar fungi, the most common of which are micromycetes of the genus Penicillium. These data are confirmed by the results of other researchers who have dealt with the problem of food contamination in the retail network. Thus, the microbiological air quality (psychotropic bacteria and air fungi) and the distribution of fungi in different types of refrigerators for food storage in retail stores in town Edirne, Turkey were determined (Altunatmaz et al., 2012). Penicillium(29.0\%), Aspergillus (12.0\%), Mucor (9.0\%) and Cladosporium (8.0\%) and others were also identified as the dominant fungi in the air of refrigerators. According to Kazakova E.V. (2010) the main initiators of microbial lesions of the surface of meat products are also molds of the genus Penicillium and Aspergillus, which have a high ability to form spores.

In order to reduce the bacteriological load on the surface of sausage bulks during implementation, there is a necessity to find new universal, easy to use, safe preservatives, which, together with the availability and low cost, would be highly effective. That is why the next stage of research was to evaluate the use of synthetic protective casings which provide long-term storage of 
sausages. As a subject of research there were taken raw-smoked sausages "Braunschweigska" premium sort, "Moscovska" premium sort and "Sudzhuk" premium sort. In order to protect sausages from contamination by microorganisms during sale and with the aim to preserve the external appearance, we have selected 10 modern means that ensure the formation of a protective coating on the surface of sausage bulks. It should be noted that the hygiene of packaging, along with other requirements, is strictly regulated by EU regulations 93/43/EWG, as well as LMG 1975 § 28 on food hygiene, and therefore any materials that come into contact with food should not have a negative impact on their quality and safety.

Visual evaluation of ready-to-sell sausage bulks, on which were additionally applied experimental synthetic coatings, showed that all samples had the traditional external appearance for this type of product, with a clean, dry surface, without damage to the shrink. It should be noted that compared to the traditional technology of production of raw-smoked sausages, the surface of the prototypes was smooth and matte-shiny shade. According to the results of organoleptic evaluation of experimental samples of sausages, no deviations in physicochemical parameters were detected in accordance with DSTU 4427: 2005 "Rowsmoked and cured sausages. General technical conditions" (Table 3).

Table 3. The results of physico-chemical studies of row-smoked sausages before processing $(n=6, M \pm m)$

\begin{tabular}{|c|c|c|c|c|}
\hline \multirow{2}{*}{ Indices } & \multicolumn{3}{|c|}{ Sausage samples } & \multirow{2}{*}{$\begin{array}{c}\text { DSTU norm } \\
4427\end{array}$} \\
\hline & $\begin{array}{c}\text { "Braunschweigska" } \\
\text { r/s, p/s }\end{array}$ & $\begin{array}{l}\text { "Moscovska" } \\
\text { r/s, p/s }\end{array}$ & $\begin{array}{l}\text { "Sudzhuk" } \\
\text { r/s, p/s }\end{array}$ & \\
\hline Mass part of humidity & $27 \pm 0.5$ & $30 \pm 0.7$ & $30 \pm 0,5$ & $25-35$ \\
\hline Mass part of protein (not less, \%) & $20 \pm 2.0$ & $20 \pm 2.0$ & $25 \pm 2.0$ & 12 \\
\hline Mass part of fat (not more, $\%$ ) & $45 \pm 5.0$ & $42 \pm 3.0$ & $40 \pm 5.0$ & 65 \\
\hline Mass part of food salt (not more, \%) & $5.6 \pm 0.2$ & $5.8 \pm 0.1$ & $6 \pm 0.2$ & 6 \\
\hline $\begin{array}{l}\text { Mass part of Natrium Nitrat } \\
\text { (not more, \%) }\end{array}$ & 0.003 & 0.003 & 0.003 & 0.003 \\
\hline $\begin{array}{l}\text { Temperature inside the bulk during } \\
\text { starting in retail }{ }^{\circ} \mathrm{C}\end{array}$ & $6 \pm 1$ & $6 \pm 1$ & $6 \pm 1$ & $0-12$ \\
\hline
\end{tabular}

After applying the protective coating on the surface of the experimental sausages, they were stored at a temperature from 0 to $6^{\circ} \mathrm{C}$ and a relative humidity of $75-78 \%$ in open display refrigerator windows. Before laying the sausages on the shop -window, they were washed and disinfected with $6.0 \%$ hydrogen peroxide solution. Microbiological studies of experimental samples of sausages were performed every 5 days during 20 days period (the maximum period for the implementation of a batch of rowsmoked sausages) to detect the presence of micellar fungi on their surface (Table 4).

Table 4. The results of the development of micellar fungi on the surface of smoked sausages $(n=10, M \pm m)$

\begin{tabular}{|c|c|c|c|c|c|c|c|c|c|c|c|c|}
\hline \multirow{3}{*}{ Product name } & \multirow{2}{*}{\multicolumn{4}{|c|}{$\begin{array}{l}\text { "Braunschweigska" } \\
\text { r/s, p/s }\end{array}$}} & \multirow{2}{*}{\multicolumn{4}{|c|}{$\begin{array}{c}\text { "Moscovska" } \\
r / s, p / s \\
\text { d of investigating, day }\end{array}$}} & \multirow{2}{*}{\multicolumn{4}{|c|}{$\begin{array}{l}\text { "Sudzhuk" } \\
\text { r/s, p/s }\end{array}$}} \\
\hline & & & & & & & & & & & & \\
\hline & 5 & 10 & 15 & 20 & 5 & 10 & 15 & 20 & 5 & 10 & 15 & 20 \\
\hline Optiglianets & - & - & - & - & - & - & - & - & - & - & - & - \\
\hline Blendex Tauchmasse & _- & - & + & + & _- & - & + & + & - & - & + & + \\
\hline Improved Protective Tauchmasse & - & - & + & + & - & - & + & + & - & - & + & + \\
\hline CoatStar 110 & - & - & - & - & - & - & - & - & - & - & - & - \\
\hline Polisved-1 & - & - & - & - & - & - & - & - & - & - & - & - \\
\hline Special food mixture & + & + & + & + & + & + & + & + & + & + & + & + \\
\hline Antibak Tauchmassa & - & - & - & - & - & - & - & - & - & - & - & - \\
\hline Aspick & + & + & + & + & + & + & + & + & + & + & + & + \\
\hline $\begin{array}{l}\text { Latex coating for sausages and chees } \\
\text { Tauchmasse }\end{array}$ & - & - & - & + & - & - & - & + & - & - & - & + \\
\hline Tauchmasse KP-15 & - & - & - & - & - & - & - & - & - & - & - & - \\
\hline
\end{tabular}

Note: «+»- the presence of growth of micellar gyphy; «-»- mark of the growth of micellar fungi. 
It was found that the use of protective coating “Optiglyanets" (Lofink Group, Ukraine), “CoatStar 110" (OJSC "Upakprint”, Russia), "Polisved-1" (OJSC “Omega", Russia), “Antibak Tauchmassa” (Company “SWEDE HOLDING, Russia) and "Tauchmasse KP-15” (Italy) delays the development of micellar fungi (up to 20 days) on the surface of prototypes of row-smoked sausages, and thus provides microbiological stability of prototypes throughout the implementation period. In addition, their use ensures the preservation of the external appearance of products. However, it should be noted that in the process of storage of ready sausages there is a loss of weight of sausage bulks, which is due to the removal of moisture through the surface layer. Thus, while storage for 20 days, the weight loss of smoked sausages without a protective film was $20.4 \pm 1.7 \%$. When using the protective coating "Optiglyanets" (Lofink Group, Ukraine) and "Polisved-1" (OJSC "Omega", Russia) in the technology of production of row-smoked sausages, their weight loss was $14.5 \pm 0.8 \%$, and therefore the use of this protective coating reduces losses weight of sausage bulks in 0,6 times.

The relevance of these studies is of Kazakova E.V confirmed her works. (2010). She proves that protective coatings and shrinks for sausage products create a fairly strong protein matrix and have a number of functional properties which are necessary for the formation of the safety meat products. The combination of hydrogel coatings with curcumin and UV-A light has been shown to have great potential as antimicrobial coatings to prevent cross-contamination of L. inocua in sausages (Tosati et al., 2018). It is noted that the use of chitosan shrinks and coatings has led to longer shelf life and reduced lipid peroxidation of meat products (Yuan et al., 2016). Quality control of sausage products by using modern research methods remains relevant (Paliy et al., 2020a). Compliance with modern biosafety requirements at meat processing enterprises is the key to obtain high-quality and safe food (Paliy et al., 2020b).

\section{Conclusions}

It was found that the germination of micellar fungi on sausage bulks of row-smoked sausages begins on the $5^{\text {th }}$ day of their sale in the retail network, but more massive and intensive development of micromycelia was found on the $20^{\text {th }}$ day of sale. It is proved that after 20 days of sale, row-smoked "Braunschweigska" is covered with a mold in $29.32 \pm 8.16 \%$ of cases, which is almost 5 times as much as in 5 days.

During sale in retail stores, the surface of sausages is contaminated with molds: Penicillium(62.9\%), Aspergillus(18.2\%), Mucor (10.7\%), Cladosprium (4.5\%). In addition, 3.7\% induced other types of microscopic fungi, which are not significant in the mold of sausages.

Use of protective coating "Optiglanets" (Lofink Group, Ukraine), “CoatStar 110" (OJSC “Upakprint”, Russia), "Polisved-1" (OJSC "Omega", Russia), "Antibak Tauchmasse" (Company "SWED HOLDING", Russia) and "Tauchmasse KP-15" (Italy) delays the development of micellar fungi on the external surface of prototypes of row-smoked sausages for 20 days. When using in the technology of production of smoked sausages protective coating "Optiglyanets" (Lofink Group, Ukraine) and "Polisved-1" (JSC "Omega", Russia), their weight loss is the lowest compared to other protective coatings, and amounted to $14.5 \pm 0.8 \%$, and therefore reduces the weight loss of sausage bulks by 0.6 times.

The obtained research results were tested and implemented in production at the meat processing enterprises of private agricultural enterprise "Agrofirma Privolye" (village Privolye, Troitsky district, Luhansk oblast) and the company "Myasosphere" (t. Severodonetsk, Luhansk oblast).

Prospects for further research are to develop modern protective shrinks/coatings of Ukrainian production for cured and rowsmoked sausages and to study their toxic effects on the final product.

\section{References}

Abrunhosa, L., Morales, H., Soares, C., Calado, T., Vila-Chã, A. S., Pereira, M., \& Venâncio, A. (2016). A review of mycotoxins in food and feed products in Portugal and estimation of probable daily intakes. Critical reviews in food science and nutrition, 56 (2), 249-265. doi: 10.1080/10408398.2012.720619

Acevedo-Fani, A., Salvia-Trujillo, L., Rojas-Graü, M. A., \& Martín-Belloso, O. (2015). Edible films from essential-oil-loaded nanoemulsions: Physicochemical characterization and antimicrobial properties. Food Hydrocolloids, 47 (2015), 168-177. doi: 10.1016/j.foodhyd.2015.01.032

Altunatmaz, D. K., Issa, G., \& Aydin, A. (2012). Detection of airborne psychrotrophic bacteria and fungi in food storage refrigerators. Braz. J. Microbiol., 43 (4), 1436-1443. doi: 10.1590/S1517-838220120004000027

Boonviset, P., \& Pirak, T. (2020). Physicochemical and sensory characteristics of reduced fat-low sugar Chinese pork sausage as produced by chitooligosaccharide using commercial pectinase hydrolysis. International Journal of Food Properties, 23 (1), 22-33. doi: 10.1080/10942912.2019.1702998

Cagri, A., Ustunol, Z., \& Ryser, E. T. (2004). Antimicrobial edible films and coatings. Journal of food protection, 67 (4), $833-848$. doi: $10.4315 / 0362-028 x-67.4 .833$

de Barros, J. R., Kunigk, L., \& Jurkiewicz, C. H. (2010). Incorporation of nisin in natural casing for the control of spoilage microorganisms in vacuum packaged sausage. Brazilian Journal of Microbiology, 41 (4), 1001-1008. doi: 10.1590/S151783822010000400019

Delgado, J., Peromingo, B., Núñez, F., \& Asensio, M. (2016). Use of molds and their antifungal proteins for biocontrol of toxigenic molds on dry-ripened cheese and meats. Current Opinion in Food Science, 11, 40-45. doi: 10.1016/j.cofs.2016.09.003

Frisvad, J. C. (2018). A critical review of producers of small lactone mycotoxins: patulin, penicillic acid and moniliformin. World Mycotoxin Journal, 11 (1), 73-100. doi: 10.3920/WMJ2017.229 
Holck, A., Axelsson, L., McLeod, A., Rode, T. M., \& Heir, E. (2017). Health and Safety Considerations of Fermented Sausages. Journal of Food Qualiti, 2017, ID 9753894. doi: 10.1155/2017/9753894

Iacumin, L., Chiesa, L., Boscolo, D., Manzano, M., Cantoni, C., Orlic, S., \& Comi, G. (2009). Moulds and ochratoxin A on surfaces of artisanal and industrial dry sausages. Food Microbiology, 26 (1), 65-70. doi: 10.1016/j.fm.2008.07.006

Iacumin, L., Manzano, M., Panseri, S., Chiesa, L., \& Comi, G. (2016). A new cause of spoilage in goose sausages. Food Microbiology, 58, 56-62. doi: 10.1016/j.fm.2016.03.007

Ismaiel, A. A., \& Papenbrock, J. (2015). Mycotoxins: Producing Fungi and Mechanisms of Phytotoxicity. Agriculture, 5, $492-537$. doi: 10.3390/agriculture5030492

Jessen, B., \& Lammert, L. (2003). Biofilm and disinfection in meat processing plants. International biodeterioration \& biodegradation, 51 (4), 265-269. doi: 10.1016/S0964-8305(03)00046-5

Kim, J. H., Pyun, C. W., Hong, G. E., Kim, S. K., Yang, C. Y., \& Lee, C. H. (2014). Changes in physicochemical and microbiological properties of isoflavone-treated dry-cured sausage from sulfur-fed pork during storage. Journal of animal science and technology, 56, 21. doi: 10.1186/2055-0391-56-21

Kocić-Tanackov, S., Dimić, G., Mojović, L., Gvozdanović-Varga, J., Djukić-Vuković, A., Tomović, V., Šojić, B., \& Pejin, J. (2017). Antifungal Activity of the Onion (Allium cepa L.) Essential Oil Against Aspergillus, Fusarium and Penicillium Species Isolated from Food. Journal of Food Processing and Preservation, 41 (4), e13050. doi: 10.1111/jfpp.13050

Marchiore, N. G., Manso, I. J., Kaufmann, K. C., Lemes, G. F., Pizolli, A. P. de O., Droval, A. A., Bracht, L., Gonçalves, O. H., \& Leimann, F. V. (2017). Migration evaluation of silver nanoparticles from antimicrobial edible coating to sausages. LWT Food Science and Technology, 76 (2017), 203-208. doi: 10.1016/j.Iwt.2016.06.013

Martins, A. P., Martins, H. H. de A., Isidoro, S. R., Alcântara, J. P., Ramos, E. M., \& Piccoli, R. H. (2019). Changes in the quality of sliced mortadella sausages prepared using chitosan. Journal of Food Safety, 2019, e12645. doi: 10.1111/jfs.12645

Paliy, A. P., Rodionova, K. O., Braginec, M. V., Paliy, A. P., \& Nalivayko, L. I. (2018). Sanitary-hygienic evaluation of meat processing enterprises productions and their sanation. Ukrainian Journal of Ecology, 8 (2), 81-88. doi: 10.15421/2018_313

Paliy, A. P., Rodionova, K. O., \& Paliy, A. P. (2017). Contamination of Animal and Poultry Meat and the Means of its Reduction. Food Science and Technology, 4 (11), 64-71. doi: 10.15673/fst.v11i4.732

Paliy, A. P., Stegniy, B. T., Palii, A. P., Rodionova, K. O., Bogatko, N. M., Vashchyk, Ye. V., Sakhniuk, N. I., Ovcharenko, H. V., Dudus, T. V., Ihnatieva, T. M., \& Kovalenko, L. V. (2020a). Microstructural analysis of sausage quality. Ukrainian Journal of Ecology, 10 (2), 404-409. doi : 10.15421/2020_115

Paliy, A. P., Zavgorodniy, A. I., Stegniy, B. T., \& Palii, A. P. (2020b). Scientific and methodological grounds for controlling the development and use of disinfectants. Monograph. Kharkiv: «Miskdruk», 318. ISBN: 978-617-619-237-4. (in Ukrainian)

Rodionova, K. O., \& Paliy, A. P. (2018). Influence of modern vacuum packaging on quality and safety of sausage products. Journal for Veterinary Medicine, Biotechnology and Biosafety, 4 (1), 18-23.

Rodionova, K. O., Paliy, A. P., Palii, A. P., Yatsenko, I. V., Fotina, T. I., Bogatko, N. M., Mohutova, V. F., Nalyvayko, L. I., Ivleva, O. V., \& Odyntsova, T. A. (2020). Effect of ultraviolet irradiation on beef carcass yield. Ukrainian Journal of Ecology, 10 (2), 410 415. doi: $10.15421 / 2020 \_118$

Sachindra, N. M., Sakhare, P. Z., Yashoda, K. P., \& Rao, D. N. (2005). Microbial profile of buffalo sausage during processing and storage. Food Control, 16 (2005), 31-35. doi: 10.1016/j.foodcont.2003.11.002

Sánchez-Ortega, I., García-Almendárez, B. E., Santos-López, E. M., Amaro-Reyes, A., Barboza-Corona, J. E., \& Regalado, C. (2014). Antimicrobial edible films and coatings for meat and meat products preservation. Scientific World Journal, 2014, 248935. doi:10.1155/2014/248935

Topal, R. S. (2004). The mycotoxin profiles and dominant mycoflora distribution in foods and agricultural products in Turkey. British Food Journal, 106 (7), 494-511. doi: 10.1108/00070700410545700

Tosati, J. V., Oliveira, E. F., Oliveira, J. V., Nitin, N., \& Monteiro, A. R. (2018). Light-activated antimicrobial activity of turmeric residue edible coatings against cross-contamination of Listeria innocua on sausages. Food Control, 84, 177-185. doi: 10.1016/j.foodcont.2017.07.026

Viera, V. B., Piovesan, N., Moro, K. I. B., Rodrigues, A. S., Scapin, G., Rosa, C. S., \& Kubota, E. H. (2016). Preparation and microbiological analysis of Tuscan sausage with added propolis extract. Food Science and Technology, 36 (1), 37-41. doi: 10.1590/1678-457x.0045

Wang, Q., Wang, J., Ding, W., Zhang, D., Reed, K., \& Zhang, B. (2018). Alternatives to carcinogenic preservatives in Chinese Sausage - Sorbic acid-loaded chitosan/tripolyphosphate nanoparticles. International journal of biological macromolecules, 120 (Pt A), 28-33. doi: 10.1016/j.ijbiomac.2018.08.034

Wu, S. J., Pan, S. K., Wang, H. B., \& Wu, J. H. (2013). Preparation of Chitooligosaccharides from Cicada Slough and Their Antibacterial Activity. Int. J. Biol. Macromol., 2013, 62, 348-351. doi: 10.1016/j.ijbiomac.2013.09.042

Yuan, G., Chen, X., \& Li, D. (2016). Chitosan films and coatings containing essential oils: The antioxidant and antimicrobial activity, and application in food systems. Food Research International, 89 (Part 1), 117-128. doi: 10.1016/j.foodres.2016.10.004

\section{Citation:}

Rodionova, K.O., Paliy, A.P., Palii, A.P., Yatsenko, I.V., Bogatko, N.M., Vashchyk, Y.V., Zolotaryova, S.A., Nalyvayko, L.I., Zolotarev, A.P., Ovcharenko, H.V. (2020). Improvement of storage resistance of sausage products to micellar mushrooms by synthetic protective shrinks. Ukrainian Journal of Ecology, 104), 242-249

(cc) Br 